\title{
AN APPRAISAL OF MAJOR ENGLISH COURSES FOR BACHELOR'S OF ARTS
}

\author{
Sushil Lamichhane*
}

\begin{abstract}
The purpose of this article is to identify the strong and weak aspects of the major English courses of three year Bachelor's programme under the faculty of Humanities and Social Sciences in Tribhuvan University. This article is primarily based on the library research along with the discussions carried out with the teachers of major English. The courses are appropriate and relevant as they impart the knowledge of both literature and literary theories but have holes in the system of teaching learning activities and evaluation system. This article attempts to provide some suggestions for pedagogic implications to the concerned authorities accordingly.
\end{abstract}

Key words: Bachelor's level courses, major English, analysis, relevance, strengths, weaknesses.

\section{INTRODUCTION AND OBJECTIVE}

This article attempts to analyze the existing courses of B.A major English under the Faculty of Humanities and Social Sciences in Tribhuvan University. The students of major English in B.A. level have faced many problems in grasping the knowledge and skills from the theory plus literature based courses due to many problems even though the courses have link up with the courses of higher secondary education. Students are also baffled with by the techniques applied by the teachers in teaching learning process. The courses are designed to evaluate the students only by the annual evaluation system. The teaching and evaluation system has also created problems to the students to internalize the literary theories. Many teachers become unfriendly to the students to impart more practical approach of teaching because they feel that they have no role in evaluating the students. This leads to the decrease in the qualities as well as size of the students in the subjects. So, this article has tried to evaluate how far the prescribed courses are suitable and whether the instructional techniques, evaluation schemes the courses include are strong and relevant. It will be helpful to English teachers and major English students who face difficulties

* Mr. Lamichhane is Teaching Assistant in English, Bhojpur Multiple Campus, Bhojpur, TU. 
in dealing with these courses and others who are interested in English will also be benefited. This article analyzes only the existing courses of major English in three year Bachelor's level under the faculty of Humanities and Social Sciences.

Students of major English at Bachelor level in Humanities and Social Sciences, TU have to take five papers. Although the senior teachers through their papers in seminars have tried to provide different guidelines to make teaching learning activities more effective to achieve the goals of the courses, none of them have tried to analyze these courses systematically and critically. The problem with reference to the use of these courses still lies in their instructional techniques and evaluation system. The study had the following objectives:

- to analyze and evaluate the major English courses of three year Bachelor's of Humanities and Social Sciences in TU.

- to find out the strengths and weaknesses of the courses.

- to suggest for pedagogic implications.

Ghimire (2003) completed a research work entitled An Analysis of Link English Course for PCL First Year and Grade XI. The main objective of this study was to analyze the Link English course in term of its adequacy of the contents. It was concluded that the text book lacks emphasis on oral practices. In his similar research entitled An Analysis of the Textbook Expanding Horizons in English, Joshi (2010) concluded that the textbook had given sufficient exercises; more focus was given to reading and writing. The textbook encompassed meaningful items for reading although it was not free of criticism.

In his workshop paper, Pandey (2017) mentioned that the main problem of teaching literary texts to the B.A. level students is the lack of teach ability. He concluded that the traditional lecture method and the habit of teachers had been making the teaching learning activities more problematic in this level. Joshi (2017) in his workshop paper has pointed out that it was difficult to deal with poetry because poetry was complex in it's nature, form and subject matter. He suggested to follow the system of language of poetry to understand a poem. None of the above mentioned reviewed works analyzed and explored the strengths and weaknesses of the courses of B.A. major English. This article has somehow tried to analyze the courses and present strengths and weaknesses respectively. 


\section{ANALYSIS METHOD AND INTERPRETATION}

This article is primarily based on library research and textual analysis.

- Introduction of the Courses: The existing major English courses for the three year Bachelor's level had been effective since 2065 B.S. According to the syllabus compiled by TU Curriculum Center (2008) the courses were designed with the following objectives.

- To equip students with a sound background for the serious study of literature.

- To give students standard and cutting edge materials to study.

- To give students appropriate tools for interpreting, understanding and creating texts.

The courses are comprised of 5 papers, each carrying 100 marks. The courses are theoretical in nature. Among these papers, the students in the first year should study one paper, likewise two papers in the second year, and two papers in the third year respectively (Table 1).

Table 1: Courses Title and Assigned Year.

\begin{tabular}{|l|l|l|l|}
\hline Code No. & Paper & Course Title & Year \\
\hline Eng. 311 & First & $\begin{array}{l}\text { Western Intellectual Tradition and Literary } \\
\text { Theory }\end{array}$ & First \\
\hline Eng. 312 & Second & Prose :Essays and Short Stories & Second \\
\hline Eng. 313 & Third & Drama and Film & Second \\
\hline Eng. 314 & Fourth & Poetry & Third \\
\hline Eng. 315 & Fifth & Critical Thinking and Practical Criticism & Third \\
\hline
\end{tabular}

Source: Curriculum Development Centre, TU (2008).

The first paper of B.A Major English consists of two components, i.e. Essays on Western Intellectual Tradition and Literary Theories. Essays on Western Intellectual Tradition covers twelve essays and in Literary Theory seven different theories are introduced and gives the ways to analyze a text. In this section, The Great Gatsby a novel by F. Scott Fitzgerald has been analyzed using different approaches to literary criticism. The second paper of B.A major English course is prose and it consists of essays and short stories. This paper aims to introduce the elements of essays and fiction to the students. In essay section, students are prescribed to read four essays with commentaries and other six essays by different writers. In short stories 
section, students are prescribed twelve stories to read and the commentaries of three stories have been mentioned. Here students should read and discuss the stories on the basis of its theme. The weight age of both sections is equal. The third paper of B.A major English course consists of Drama and Film. This paper aims to introduce context, modes and elements of drama. It also aims to introduce the elements of film. In drama section, four dramas are prescribed to deal with their different aspects. In film section, elements of film is given with more priority. The drama section covers 80 percent weight age and film section covers 20 percent weight age respectively. The fourth paper of B.A major English course consists of poetry. This paper aims to introduce the elements of poetry, analyzes twenty seven different poems of writers of different periods. Here the students can approach the poems theme wise and style wise. The fifth paper is Critical Thinking and Practical Criticism. This paper aims to introduce creative and critical thinking to the students and to analyze a text by applying different theories. This paper provides a considerable section of logic and the use of language in critical and creative thinking. It also provides some texts for the application of modern literary theories.

Relevancy and integration of contents of the courses: The contents of the existing courses of B.A major English seem appropriate for the Bachelor's level as they have been developed on the root of Higher Secondary major English. The students will easily entertain the courses by optimum utilizing their previous background of English literature and language. The courses provide adequate knowledge about literary theory through different forms of literature. The courses are relevant with the need of education system of the contemporary society. The relevancy of the courses is very important to fulfill the objectives of the need of students, society and the nation. Following this spirit, KC (2008) focuses on the need based syllabus, it finally increases the implementation level of the courses and they will certainly increase the needs and wants of the learners, society and the nation at large and in a better way. The courses are relevant for this level due to their realistic and attainable objectives. The organization of the courses is much specified. The courses show vertical and horizontal relationship making linkage with Higher Secondary and M.A. major English. They provide the knowledge of theory and literary moments. The literary genre like poetry, drama, essay, short story, novel etc. prescribed in the courses help to build up the concept of the elements of literature, approaches of analyzing a text B.A major English course also have horizontal relationship with each other. The first 
and the fifth paper both provide the knowledge of theory and the ways of analyzing the text on the light of different theories. Practical Criticism component of the fifth paper is totally based on the literary theory section of the first paper. Second, the third and the fourth paper are also interrelated in their theme, movement, style, subject matter, etc. The courses provide texts from both American and British writers. We can find integration of theoretical and literary aspects in these courses. These courses are the continuity of Higher Secondary major English courses and provide the way ahead for M.A. major English courses.

Instructional techniques and evaluation system: The major English courses of three year B.A do not clearly provide the instructional techniques for teaching learning activities. The courses give freedom to the teachers to choose the suitable teaching methods. The teachers can use lecture method as well as discussion method to make their class more effective. Supporting this view, Thapa (2017) focuses on the use of reflective and questioning methods for teaching learning activities. He suggests to carry out the suitable method as the teacher thinks to make his teaching relevant. For teaching literary theory, he further recommends that the course calls for reorienting our teaching towards more reflective and questioning pedagogy. A decade long practice of teaching literature in Bachelor's level shows that the contextual method is more suitable. Suggesting in the use of suitable pedagogy of teaching theory, Pandey (2016) focuses on the internalizing the literary theory to the teachers by using the right kind of pedagogy. The teachers should encourage students to look the text from different theoretical perspectives. Likewise, for teaching drama, role play, group work, peer work, dramatization will become more effective if applied properly. Discussions with the teachers showed that close, careful reading of poem and recitation are suitable methods for teaching poetry. The teacher should focus on performance to make poetry class more effective. Careful consideration of the poem's overall design such as language, figures of speech, structure, style, title, theme, etc. Are necessary for analyzing the poem. The teacher should provide the students with sufficient knowledge of the poem's background like time, view point and cultural context to make the message of the poem clear. Since the courses do not suggest instructional techniques in specific, there is enough space to use lecture method and it has been one of the reasons of losing opportunity to achieve expected results in B.A. major English. 
The evaluation system of B.A major English courses are conventional annual examination system. There is no role of teacher in evaluating the students. Even though this kind of evaluation system is suitable for the job holder and irregular students as it follows the marking system and they do not have to complete the assignment, it can not evaluate the students 'practical knowledge. The courses lack the student centered evaluation system. In this evaluation system, students are only focused for final examination.

Resource materials and time allocation: Three year Bachelor's level major English courses have advanced courses to fulfill the general objectives of this level. Text books are easily available in Nepali market. Reference books of some papers are not easily available throughout the country. For the reference books, the students should depend upon the tutors and libraries. Sometimes teachers are also suffering from the lack of reference books. All the courses have limited time hours. Teachers are given 150 hours to complete each course. But due to seen and unseen hindrances; many teachers are unable to complete their courses in time. To cope with this, teachers can connect one course with other courses or with previous knowledge that the students have already acquired. For example, to teach the fifth paper, the teacher can connect with the first paper and can maximum utilize the time on the new issues.

\section{Strengths of the courses}

The major English courses of three year Bachelor's level have following strengths:

- The courses attempt to impart the skills of inquiry, logical reasoning and taste for reading literature in students.

- The courses attempt to look forward to making linkage to the M.A. major English and have prepared the ground for a more critical and detailed study of literature and other human disciplines at the post graduate level.

- The courses attempt to fulfill the general objectives of the three year B.A. level and the national objectives of education of our country.

- The courses try to explain the main literary theories at present and provide the ways to analyze literary texts by applying those theories. 
- The courses bring together the varieties of prose (essays, short stories, novel), poetry and dramas of different periods with different issues.

- The textbooks prescribed in the courses are very suitable to fulfill the objectives of the course of study and they are easily available in the Nepalese markets in low price.

- The courses provide the teachers with enough space to use any instructional technique; as a result, teachers are free to use suitable teaching method to apply for effective teaching learning activities according to the context.

\section{Weaknesses of the courses}

The major English courses for the three years Bachelor's level have the following weaknesses:

- The courses do not explore the social, political cultural and economic aspects of Nepalese Society. Nepalese students are not familiar with the contexts shown in the courses.

- The courses cover no or less language portion in the contents which is essential to study and analyze the literary texts.

- The courses do not sufficiently discuss about the burning issues of present time.

- Some papers are theoretical and lengthy, so there is a bit challenge to complete the course in the limited boundary of time.

- Text books prescribed in the courses are available in the market but the reference books are not easily available in the Nepalese market, even if they are available, it is very costly for the students.

- The courses lack the student centered evaluation system.

\section{CONCLUSION}

In nutshell, the three year Bachelor's level major English courses attempt to develop the linkage between the Higher Secondary and M.A. major English courses of T.U. by introducing literature and theory. The courses also introduce some important literary tools which are basic to apply, to interpret and to peel down the meaning of a text. The courses are useful to develop in students the skills of logical reasoning, inquiring, synthesizing and interpreting. The main problems of the courses lie in the evaluation system and the pedagogy that need through change. The courses will be stronger and market friendly if the following points are considered. 
- The courses should include the burning issues of contemporary society.

- The courses should focus more on practical aspects rather than only theoretical aspects.

- Language portion should be increased in the courses.

- The courses should be designed to explore social, political, cultural, and economic aspects of our society. For this well written materials of Nepalese authors should be included in the courses.

- Evaluating students through only annual examination system should be changed and internal evaluation system should be implemented. Teachers should be encouraged for changing their teaching and should apply student centered method.

\section{WORKS CITED}

Ghimire, P.B. (2003). An Analysis of the Link English Course for PCL first year and Grade XI. Kirtipur: An unpublished M.Ed. thesis submitted to faculty of Education, TU.

Joshi, A.R. (2017). Reading the Language of Poetry. An unpublished workshop paper presented at the workshop of TU English teachers. Biratnagar: TU.

Joshi, M.R. (2010). An Analysis of the Textbook 'Expanding Horizons in English' .An unpublished M.Ed. thesis submitted to faculty of Education, Surkhet Campus. TU.

KC, K.B. (2003). Critical analysis and evaluation of the existing compulsory english syllabus of higher secondary. Journal of NELTA.Vol.8, (1-2). Kathmandu: NELTA.

Pandey, B. (2017). Practice of Critical Theory in College Classroom. An unpublished workshop paper presented at the workshop of TU English teachers. Biratnagar: TU.

Thapa, A. (2017). Critical Thinking and Practical Criticism: An Introduction to the Course and Proposed Teaching Strategies.An unpublished workshop paper presented at the workshop of TU English teachers. Biratnagar: TU.

TU Curriculum Centre, (2008). Curriculum for three year bachelor level programme in English. Kirtipur: Curriculum Development Center, TU. 